\title{
Paleobiological Perspectives on Early Microbial Evolution
}

\author{
Andrew H. Knoll \\ Department of Organismic and Evolutionary Biology, Harvard University, Cambridge, Massachusetts 02138 \\ Correspondence: aknoll@oeb.harvard.edu
}

Microfossils, stromatolites, and chemical biosignatures indicate that Earth became a biological planet more than 3.5 billion years ago, making most of life's history microbial. Proterozoic rocks preserve a rich record of cyanobacteria, including derived forms that differentiate multiple cell types. Stromatolites, in turn, show that microbial communities covered the seafloor from tidal flats to the base of the photic zone. The Archean record is more challenging to interpret, particularly on the question of cyanobacterial antiquity, which remains to be resolved. In the late Neoproterozoic Era, increasing oxygen and radiating eukaryotes altered the biosphere, with planktonic algae gaining ecological prominence in the water column, whereas seaweeds and, eventually, animals spread across shallow seafloors. From a microbial perspective, however, animals, algae, and, later, plants simply provided new opportunities for diversification, and, to this day, microbial metabolisms remain the only essential components of biogeochemical cycles.

W live on a planet that records its own history, encrypted in the physical and chemical features of sedimentary rocks (Knoll 2003). Part of this history is biological; as appreciated by every child who has visited a natural history museum, bones and shells furnish a remarkable chronicle of animal evolution, complete with dinosaurs, trilobites, and other evocative taxa. The fossil record of animals extends nearly 600 million years into the past, but comparative biology makes it clear that diverse microorganisms populated our planet long before animals first evolved. The Earth itself is $>4.5$ billion years old, and the known sedimentary record begins with highly metamorphosed sedimentary rocks deposited $\sim 3.8$ billion years ago. To what extent do Earth's older sedimentary rocks provide a direct and informative record of our planet's deep evolutionary history?

\section{BIOLOGICAL SIGNATURES OF BACTERIA AND ARCHAEA}

It surprises no one that the mineralized skeletons of tyrannosaurs should leave a phylogenetically and functionally tractable record in sedimentary rocks. That the same could be true for bacteria is less obvious. How can bacterial cells, tiny and apparently evanescent, impart a geologic signature to the sedimentary record? And even if we find bacterial fossils, can they be interpreted with confidence in terms of phylogeny or energy metabolism?

Editor: Howard Ochman

Additional Perspectives on Microbial Evolution available at www.cshperspectives.org

Copyright (C) 2015 Cold Spring Harbor Laboratory Press; all rights reserved; doi: 10.1101/cshperspect.a018093

Cite this article as Cold Spring Harb Perspect Biol 2015;7:a018093 
A.H. Knoll

The processes by which a microbial record is inscribed into sediments have recently been reviewed in detail (Knoll et al. 2012), so a brief synopsis will suffice here. Bacteria can preserve conventionally as microfossils, given the pres- ence of walls or extracellular envelopes that resist postmortem decay (Fig. 1). (No one, to the best of my knowledge, has yet reported an archaeal microfossil.) That is, just as the shells and bones of animals may be incorporated into the sedi-
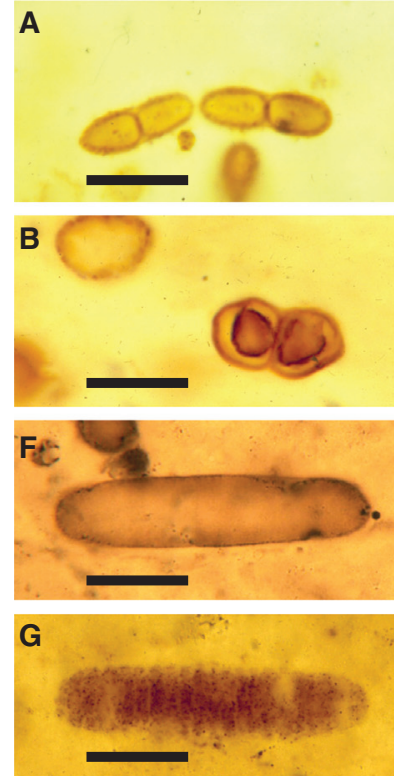

$\mathbf{J}$

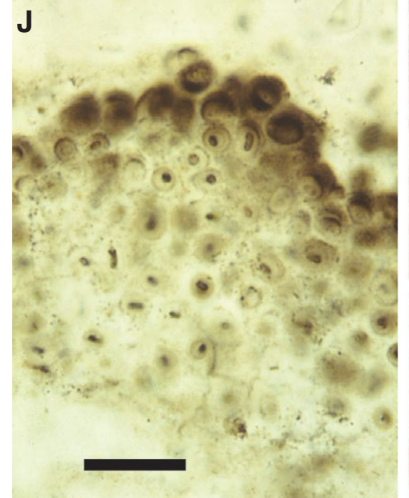

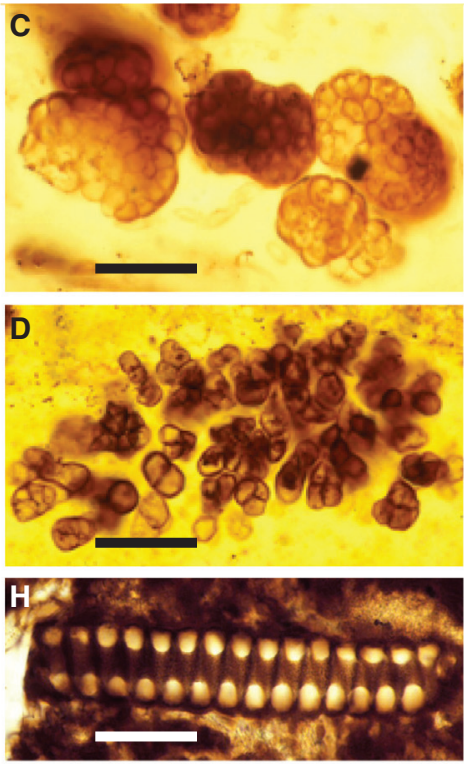
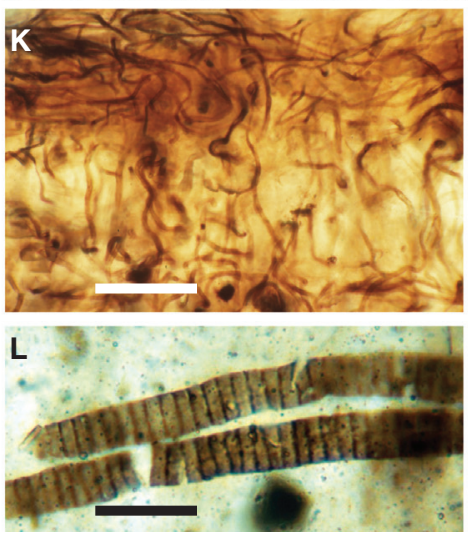
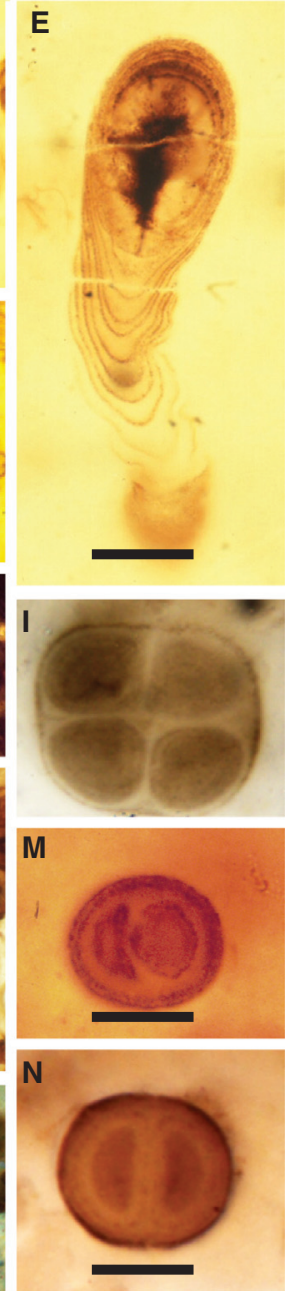

Figure 1. Proterozoic fossils interpreted as cyanobacteria. $(A-C)$ Coccoidal microfossils, some showing evidence of binary fission, 750- to 800-million-year-old (Ma) Draken Formation, Spitsbergen. (D) Hyella-like endolithic microfossil penetrating an ooid, 750 to 800 Ma Upper Eleonore Bay Group, Greenland; upper surface of ooid arcs just above the fossil. (E) Cyanostylon-like stalk-forming cyanobacterium, Draken Formation. $(F, G)$ Interpreted akinete and associated germling-like short trichome, ca. 1500 Ma Kotuikan Formation, Siberia. $(H)$ Phosphatized helical Spirulina-like filament, basal Cambrian, Siberia. (I) Gloeocapsa-like cell quartet, 1100 to $1200 \mathrm{Ma}$ Angmaat Formation, Baffin Island. (J) Entophysalis-like mat-building cyanobacteria, ca. $2000 \mathrm{Ma}$ Belcher Supergroup, Hudson Bay, Canada. $(K)$ Silicified population of mat-building filaments, showing alternating vertical and horizontal filament orientations, 750- to $800 \mathrm{Ma}$ Backlundtoppen Formation, Spitsbergen. $(M, N)$ Chroococcus-like dyads from the Bitter Springs $(M)$ and Angmaat $(N)$ formations. Scale bars, $10 \mu \mathrm{m}$ $(A-C, E, M, N) ; 75 \mu \mathrm{m}(D) ; 15 \mu \mathrm{m}(F, G) ; 20 \mu \mathrm{m}(H, J, L) ; 25 \mu \mathrm{m}(K)$. 
mentary record, whereas cellular tissues are not, so too can the decay-resistant bounding features of some bacteria preserve a record of microbial morphology and life cycle, even though cell contents disappear soon after death.

Burial is an integral part of fossilization, in part, because walls and envelopes are more likely to survive microbial decay when diffusion limits the availability of $\mathrm{O}_{2}$ and other oxidants. Before the advent of bioturbating animals, even a thin layer of mud would have sealed microbial remains from the overlying water column, and, so, in Earth's early geologic record, microfossils are commonly preserved as compressions, their walls or envelopes flattened between thin beds of mudstone (Fig. 1L). In contrast, mineral precipitation can fossilize microorganisms in three-dimensional detail, preserving both patterns of cell division and behaviorally informative orientations of individuals and populations. Bacterial microfossils can be replicated by calcium carbonate, pyrite, or, more rarely, the phosphate mineral apatite (Fig. 1H), but by far the best preservation is found in chert (finely crystalline silica, or $\mathrm{SiO}_{2}$ ) nodules formed within carbonate sediments soon after deposition (Fig. 1A-G,I-K,M,N). Chert preserves microfossils in remarkable detail, but this preservation is largely limited to peritidal environments in which, before the evolution of sponges and protists that secrete siliceous skeletons, silica precipitated from evaporating pore waters in coastal sediments (Maliva et al. 1989).

Together, the preferential preservation of walls and envelopes and the exceptional preservation found in peritidal cherts go a long way toward explaining why paleontologists working on older rocks emphasize the fossil record of cyanobacteria. Many cyanobacteria have (by bacterial standards) large cells, so they are readily visualized using optical microscopy. Moreover, many taxa form polysaccharide sheaths and envelopes that resist decay and so become incorporated into the geologic record. To a degree that is unusual if not unique among bacteria, cyanobacteria display a range of distinctive morphologies, facilitating systematic treatment and comparison with extant forms. Observations of natural populations and taph- onomic experiments show that cyanobacterial envelopes can preserve details of morphology and cell division, which record minute details of form and life cycle (Golubic and Hofmann 1976; Knoll and Golubic 1979; Bartley 1996). And, finally, through much of recorded Earth history, cyanobacteria were both abundant and diverse in just those settings most likely to preserve an informative microfossil record. There are, as well, good intellectual reasons to focus on cyanobacteria: they are major primary producers and the source (either directly or indirectly through their descendants, the plastids) of the oxygen that pervades the biosphere. It is our good fortune, then, that the most tractable microfossil record chronicles some of the organisms we most want to know about as Earth historians.

Microbes unlikely to form morphologically distinctive microfossils may still be recorded by distinctive chemical signatures. Proteins and nucleic acids have negligible preservation potential in Archean ( $>2500 \mathrm{Ma}$ ) and Proterozoic (2500 to $541 \mathrm{Ma}$ ) rocks, but lipids can be preserved over billion-year timescales. Particularly important are hopanoids, the geologically stable derivatives of bacteriohopanepolyols synthesized by many (but by no means all; Pearson et al. 2007) bacteria. Within sediments, functional groups are commonly stripped from these molecules, diminishing their specificity, but the molecular skeleton can survive intact. Based on observation and experiment, organic geochemists attempt to relate preserved geological molecules to specific biological sources (Summons and Lincoln 2012; Briggs and Summons 2014, and references therein). At present, lipid biosynthesis has been incompletely mapped onto microbial phylogenies, but, increasingly aided by genomic data, it is improving apace (e.g., Fischer et al. 2005; Sinninghe Damsté et al. 2005; Welander et al. 2010). Although Archaea do not have a conventional fossil record, they can leave a geological signature via membrane lipids with isoprenoid cores linked to glycerol by ether bonds (Koga and Morii 2005).

Still more biological information can be gleaned from stable isotope abundances. If, for 
A.H. Knoll

example, we go to the Bahama Banks and measure the stable carbon isotopic composition of both carbonate sediments and the organic matter incorporated into accumulating beds, we will find that, relative to carbonate, the organic matter is depleted in ${ }^{13} \mathrm{C}$ by about $25 \%$ o. The isotopic composition of the carbonate phase is pinned to that of dissolved inorganic carbon in seawater, whereas the composition of the organic matter additionally reflects enzymatically controlled isotopic fractionation during photosynthetic carbon fixation (Hayes 2001). The degree of fractionation also reflects environmental factors, such as $\mathrm{CO}_{2}$ availability, but to a first approximation, carbon isotopes record autotrophic processes in the biological carbon cycle. Different carbon fixation pathways have distinct isotopic signatures, but nearly all data suggest that the Calvin-Benson and, perhaps, WoodLjundahl pathways have governed global biological carbon fixation since Earth was young (Hayes 2001). Most heterotrophic processes impose only a small additional fractionation on organic matter, but methanogenesis can generate $\mathrm{CH}_{4}$ that is strongly depleted in ${ }^{13} \mathrm{C}$. If this biogenic methane subsequently becomes incorporated into biomass by methanotrophic microbes, C-isotopes of sedimentary organic matter can provide a record of methanogenesis, methanotrophy, and, hence, both Archaea and Bacteria in ancient microbial communities (Hayes 1994).

Oxidized (gypsum) and reduced (pyrite) sulfur in sediments similarly show isotopic differences that reflect aspects of the biological sulfur cycle, principally, dissimilatory sulfate reduction (Canfield 2001). As in the case of carbon, expressed fractionation reflects sulfate availability, as well as substrate and enzymatic discrimination (e.g., Bradley et al. 2011; Sim et al. 2011). Fractionation beyond that usually associated with sulfate reduction has been interpreted in terms of microbial disproportionation of intermediate sulfur compounds (Canfield and Teske 1996), a process that also leaves a subtle but measurable signature in the nonmass-dependent fractionation of the minor stable isotopes ${ }^{33} \mathrm{~S}$ and ${ }^{36} \mathrm{~S}$ (Johnston et al. 2005). Fractionation associated with denitrification plays a major role in determining the isotopic composition of inorganic nitrogen in the oceans and, hence, in the nitrogen preserved in marine organic matter (Altabet and Francois 1994), and microbial iron metabolism can impart measureable fraction to Fe-isotopic abundances (complicated by a similar potential for abiotic fractionation; Anbar et al. 2000; PercakDennett et al. 2011). In general, then, stable isotopes provide powerful tools for probing biogeochemical cycles in ancient ecosystems.

Microbial communities leave one other conspicuous signature in sedimentary rocks: the reef-like constructions called stromatolites (Fig. 2). Stromatolites form via interactions between microbial mat communities and physical processes of sedimentation. Mat populations trap and bind fine sediment particles and/or induce carbonate precipitation, resulting in the upward accretion of a finely laminated structure (Walter 1976; Bosak et al. 2013). Stromatolites can be flat, domed, cone-shaped, or columnar, straight or with candelabrum-like branches, and they can attain dimensions that rival those of modern coral reefs. The morphological diversity of Archean and (especially) Proterozoic stromatolites reflects the wide environmental distribution of microbial mat communities before the radiation of animals, and variations through time reflect secular changes in marine carbonate chemistry as much as the evolution of mat-building populations (Grotzinger and Knoll 1999). Specific mat-building communities can, however, leave signatures in physical textures expressed at the micron to millimeter scale (Knoll et al. 2013). Even where microbial laminae do not accrete, mats can generate diagnostic textures on the surfaces of sand beds, further demonstrating that microbial communities were widespread on ancient seafloors (Noffke 2010).

Other biosignatures exist. For example, magnetotactic bacteria synthesize chemically pure, single-domain magnetite crystals that can be preserved in sedimentary rocks (Kopp and Kirschvink 2008). For the most part, however, Earth's deep microbial history is inscribed in the form of microfossils, stromatolites, molecular biomarkers, and stable isotopes. 

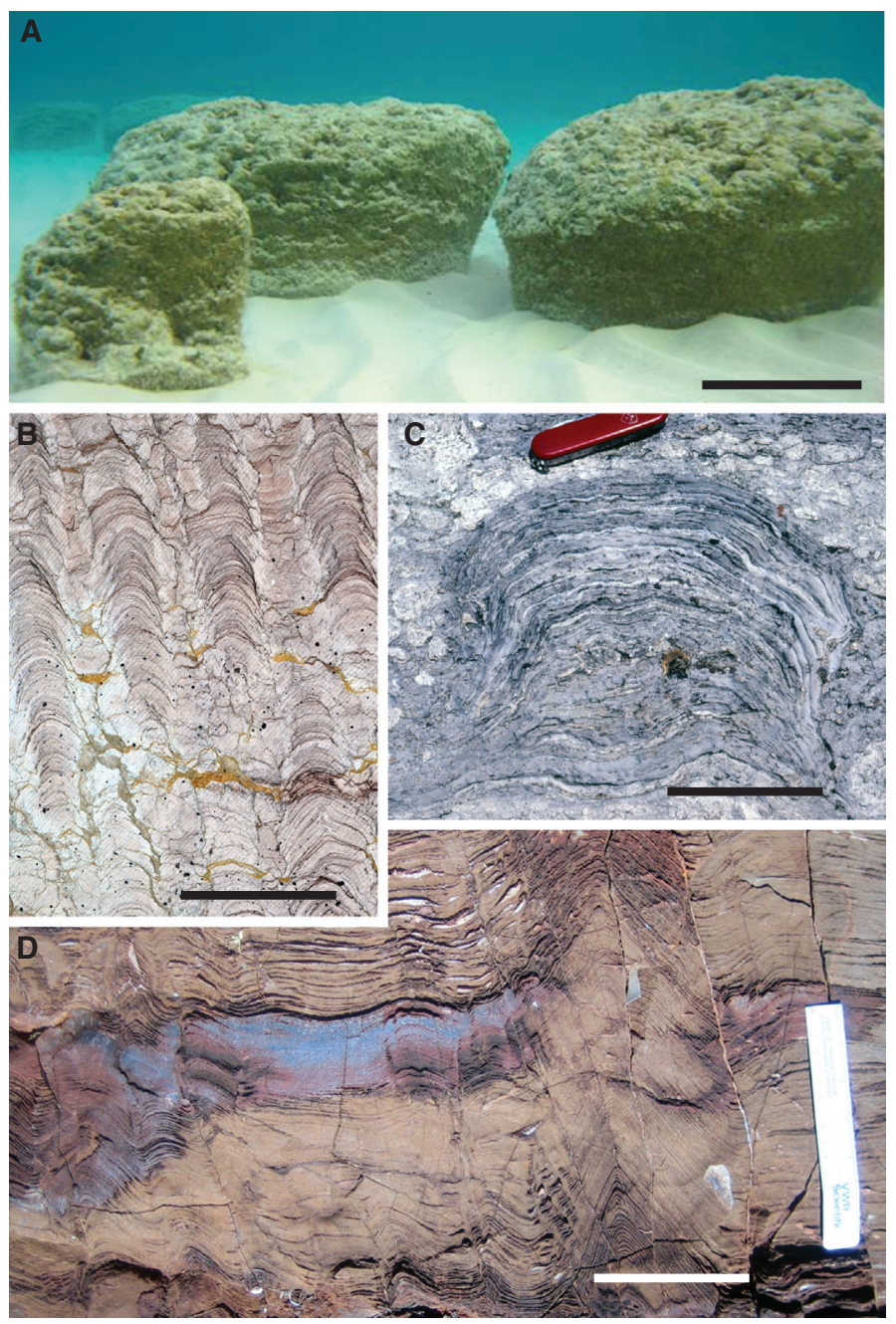

Figure 2. Stromatolites. (A) Modern stromatolites accreting subtidally in Shark Bay, Western Australia. (B) Columnar stromatolitic bioherm, ca. 800 Ma Inzer Formation, Russia. (C) Domal stromatolite from a coastal environment, ca. 800 Ma Grusdievbreen Formation, Spitsbergen. (D) Early Archean stromatolites, ca. $3400 \mathrm{Ma}$ Warrawoona Group, Western Australia; note conoidal form in right-center. Scale bars, $20 \mathrm{~cm}(A) ; 12 \mathrm{~cm}(B, C)$; $8 \mathrm{~cm}(D)$.

\section{MICROBIAL ECOSYSTEMS IN PROTEROZOIC OCEANS}

Evolutionary history can be divided into three great chapters that correspond broadly (but not precisely) to the Archean, Proterozoic, and Phanerozoic Eons recognized by geologists (Fig. 3). One might think that the story of early life should be told from the beginning, but as discussed in the next section, Archean rocks present interpretational challenges best appre- ciated in light of the better-preserved Proterozoic record. For this reason, we begin in the Proterozoic Eon, Earth's immensely long middle age that stretches from $2500 \mathrm{Ma}$ until the beginning of the Cambrian Period (and Phanerozoic Eon), 541 Ma. Unlike Archean rocks, Proterozoic sedimentary successions are widespread, relatively unaltered by hydrothermal fluid flow or metamorphism, and, importantly, richly fossiliferous. 
A.H. Knoll

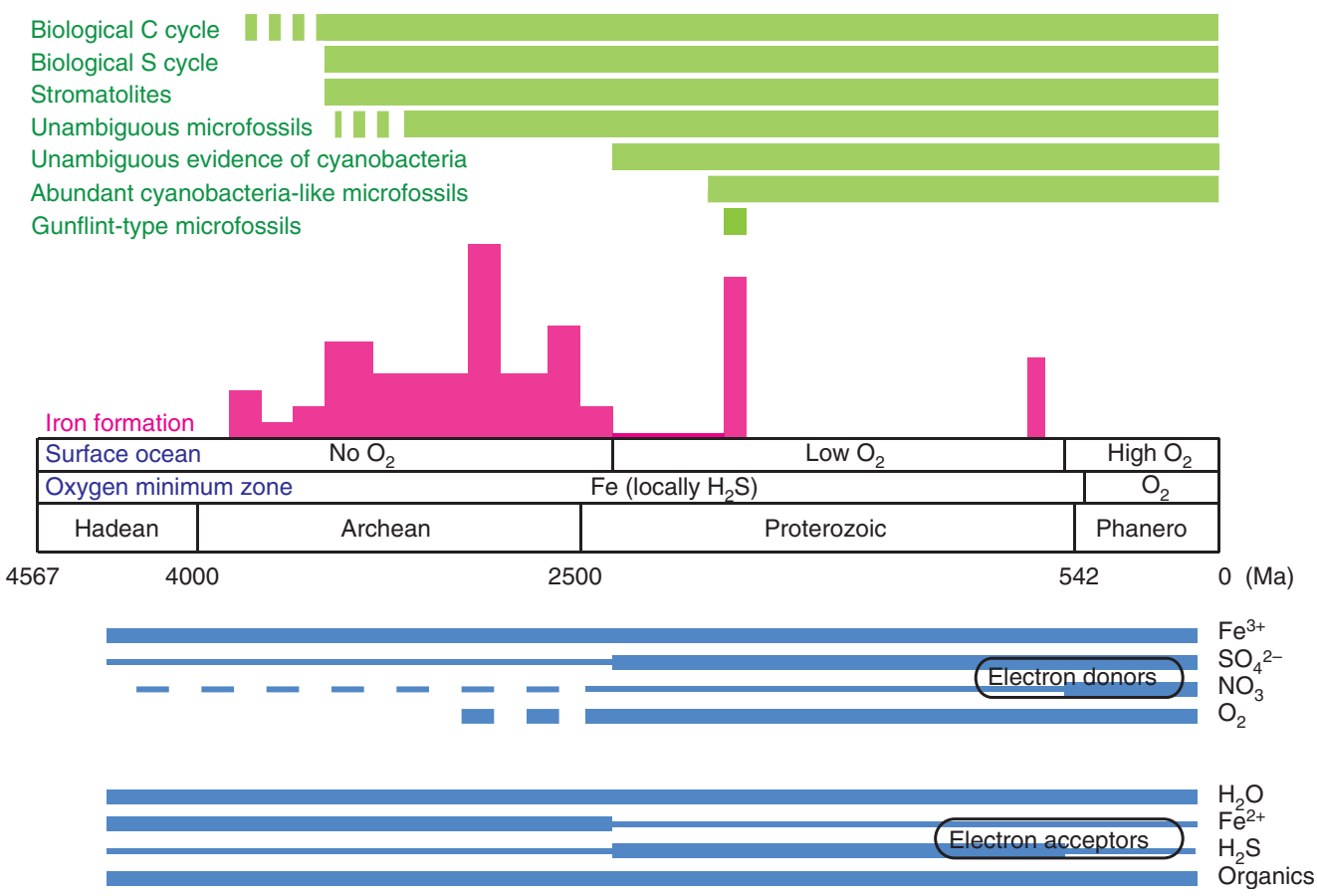

Figure 3. A summary of early microbial evolution (see the text for references).

Proterozoic cherts are full of cyanobacterialike microfossils, so much so that Schopf and Walter (1982) dubbed this interval the Age of Cyanobacteria. Without question, cyanobacteria were abundant, diverse, and widely distributed during most of the Proterozoic Era (reviewed by Knoll and Golubic 1992; Knoll 2008; Schopf 2011). Cyanobacterial phylogenies differ in detail, but generally indicate that Gloeobacter and its close terrestrial relatives are sisters to other cyanobacteria; that early branches on the cyanobacterial tree include diverse coccoidal taxa traditionally assigned to the Chroococcales, as well as some simple filaments (Oscillatoriales); cyanobacteria capable of differentiating distinct cell types (Nostocales + Stigonematales) form a derived clade within the group (e.g., Sánchez-Baracaldo et al. 2005; Tomitani et al. 2006; Shi et al. 2013). Proterozoic microfossil populations have been related with confidence to a number of extant coccoidal taxa, including species of Entophysalis (Fig. 1J) (Golubic and Hofmann 1976; Sergeev et al. 1995), Chroococcus (Fig. 1M,N) (Knoll and Go- lubic 1979). Gloeothece (Golubic and Campbell 1979), Cyanostylon (Fig. 1E) (Green et al. 1987) and Gloeocapsa (Fig. 1I) (Knoll et al. 2013), and both crust-forming and endolithic Pleurocapsaceae also have been identified (Fig. 1D) (Knoll et al. 1975; Zhang and Golubic 1987; Green et al. 1988). Filamentous taxa interpreted in terms of extant Oscillatoria, Lyngbya, Phormidium, Spirulina, and Microcoleus (Schopf 1968, 2011; Schopf and Blacic 1971; Horodyski and Donaldson 1980; Mankiewicz 1982; Sergeev et al. 1995; Knoll et al. 2013) are common in microfossil assemblages (Fig. 1H,K,L), and ellipsoidal microfossils thought to be the akinetes of nostocalean cyanobacteria occur commonly in mid-Proterozoic cherts (Fig. 1F) (Golubic et al. 1995; Srivastava 2005).

Could some of these microfossil populations be misidentified as cyanobacteria? That is certainly possible for small, simple unicells and undifferentiated filaments or their sheaths, but is unlikely for larger, more complex forms preserved in distinctive environmental settings, for example, endolithic populations indistin- 
guishable from modern Hyella (Fig. 1D) (Green et al. 1988) or fossil akinetes preserved alongside short trichomes comparable to the germlings released by akinete germination (Fig. 1F,G) (Sergeev et al. 1995; Dworkin 2006). Moreover, most silicified assemblages reflect oxygenated peritidal environments in which $\mathrm{O}_{2}$ would have restricted the availability of alternative electron donors. Regardless of possible "false positives," the wide morphological diversity of cyanobacteria-like microfossils early in the Proterozoic Eon, with akinetes documenting cell differentiation no later than $1500 \mathrm{Ma}$ (Golubic et al. 1995) and possibly as early as $2100 \mathrm{Ma}$ (Amard and Bertrand-Sarfati 1997), indicates that the major limbs of the cyanobacterial tree were established early.

Philosopher T. Shanahan (2004) proposed that progress in evolution might be gauged by "the ability to survive and reproduce despite changing environments." If we accept this criterion-and the whole concept of evolutionary progress could be debated forever (e.g., Turner 2011) — then cyanobacteria seem to outshine humans and sequoias. Such a conclusion, however, rests on two assumptions: (1) that morphological similarities between Proterozoic and living cyanobacteria reflect genuinely close functional and phylogenetic relationships, and (2) that the environments represented by cyanobacterial fossil assemblages have varied substantially through time.

How variable have peritidal environments been through time? To the extent that fitness is tied closely to the harsh physical conditions of the tidal zone, these environments actually may be unusually constant, and the cyanobacteria that colonize them may be uncommonly persistent because few eukaryotes have adapted to the chronic physical and chemical stresses associated with tidal oscillation, environmental restriction, and storms. But, the peritidal environments experienced by Proterozoic cyanobacteria surely differed from the modern in some important ways. For one thing, $\mathrm{pCO}_{2}$ was much higher (Kasting 1987) and $\mathrm{pO}_{2}$ lower, perhaps only a few percent, or less, of modern values (Partin et al. 2013; Planavsky et al. 2014). The long-term trajectories of atmospher- ic carbon dioxide and oxygen have been used to explain the Achilles' heel of oxygenic photosynthesis: the limited capacity of Rubisco to distinguish between $\mathrm{CO}_{2}$ and $\mathrm{O}_{2}$, resulting in the energetically wasteful process of photorespiration (Ogren 1984). This environmental history has also been linked to phylogenetic patterns in the optimization of the fixation rate and $\mathrm{CO}_{2}$ affinity for Rubisco (Badger et al. 1998; Tcherskez et al.2006) and the presence of $\mathrm{CO}_{2}$-concentrating mechanisms in cyanobacteria and most algae (Badger et al. 2002; Giordano et al. 2005). Fossils are unlikely to record such adaptations.

Environmental history and comparative biology, then, suggest that cyanobacteria have not been genetically static for two billion years; indeed, some ecologically important clades (for example, the Prochlorococcus strains found today in oligotrophic marine waters) (Rocap et al. 2002) have radiated relatively recently. Nonetheless, close similarities in morphology, life cycle, environmental distribution, pattern of postmortem decay, and inferred behavior strongly suggest that modern cyanobacteria provide a reasonable basis for interpreting their Proterozoic counterparts.

Stromatolites provide important proxy information on the distribution of microbial mat communities (Fig. 2); for much of the Proterozoic Eon, mats covered the seafloor from tidal flats to the base of the photic zone (Walter 1976; Grotzinger and Knoll 1999). As noted above, most of these seafloor environments were oxic, sharply limiting the availability of alternative electron donors for photosynthesis and, therefore, supporting the hypothesis that cyanobacteria were principal architects of most Proterozoic stromatolites. The abundance of 2-methylhopanoids in Proterozoic rocks has also been interpreted in terms of cyanobacterial productivity (Summons et al. 1999; Talbot et al. 2008), although the discovery of 2-methylhopanoids in other bacteria (Rashby et al. 2007; Eickhoff et al. 2013) and the absence in most marine cyanobacteria of genes required for hopanoid biosynthesis (Pearson et al. 2007) suggest a broader interpretation of biomarker data.

Despite uncertainties, it seems clear that in the moderately oxic environments of the Prote- 
A.H. Knoll

rozoic surface ocean, cyanobacteria were major primary producers, relinquishing photosynthetic dominance on continental shelves to algae only near the end of the eon (Knoll et al. 2007). Low atmospheric $\mathrm{pO}_{2}$, coupled with warm temperatures that both increased rates of respiration and decreased $\mathrm{O}_{2}$ solubility in seawater, resulted in widespread and persistent anoxia within subsurface oxygen minimum zones (Partin et al. 2013). Biomarker evidence indicates that anoxic water masses sometimes impinged on the photic zone (Brocks et al. 2005), and so anoxygenic photosynthesis also played a role in the marine carbon cycle, perhaps contributing to the persistence of low $\mathrm{pO}_{2}$ in the Proterozoic biosphere (Johnston et al. 2009).

Low $\mathrm{pO}_{2}$ may also have influenced the rates of photosynthesis in Proterozoic oceans. Many biologically important trace metals are redox sensitive, and so their availability in Proterozoic seas must have reflected the widespread distribution of subsurface anoxic, even sulfidic, water masses (Anbar and Knoll 2002; Saito et al. 2003). For example, low availability of molybdenum, needed for high-efficiency nitrogenase, may have restricted cyanobacterial nitrogen fixation (Glass et al. 2009; but see Zerkle et al. 2005). Redox structure may also have imposed a more direct limitation on the Proterozoic nitrogen cycle by minimizing nitrate levels in surface oceans and maximizing the loss of fixed nitrogen by denitrification and anammox reactions; low abundances of fixed nitrogen in many parts of the photic zone would favor primary producers able to fix nitrogen, that is, cyanobacteria and other photosynthetic bacteria (Anbar and Knoll 2002; Fennel et al. 2005; Boyle et al. 2013; Stüeken 2013).

Heterotrophs complete the carbon cycle, and geochemical evidence indicates that $\mathrm{O}_{2}$, $\mathrm{Fe}^{3+}$, and $\mathrm{SO}_{4}{ }^{2-}$ were all available for respiration in Proterozoic marine environments; because of persistently low $\mathrm{pO}_{2}$, anaerobes probably played a larger role in organic remineralization than they do today (Fig. 3). Expanded methanogenesis, expected given lower levels of sulfate in Proterozoic seawater, may be recorded by the strong $\mathrm{C}$-isotopic fractionation observed in organic-rich shales (Gilleaudeau and Kah 2013). In general, biogeochemical data suggest that the biological cycles of $\mathrm{C}, \mathrm{N}$, $\mathrm{S}$, and Fe were populated by microbes with energy metabolisms similar to those observed today, but with different fluxes and reservoir sizes.

Perhaps the most anomalous paleobiological record in Proterozoic rocks is that found in iron formations deposited 1900-1800 Ma. Iron formations are distinctly Precambrian lithologies long used to argue for oxygen limitation in the early biosphere (Fig. 4C) (Holland 2006). $\mathrm{Fe}^{2+}$ dissolves readily in seawater, whereas $\mathrm{Fe}^{3+}$ is essentially insoluble. Thus, iron formations were deposited when and where iron could be transported in solution through anoxic water masses. Precipitation of the iron could, in principle, be linked to contact with oxygen gas in surface waters, photochemical oxidation, or oxidation by autotrophic bacteria using $\mathrm{Fe}^{2+}$ as an electron donor (Kappler et al. 2005).

For many years, iron formations were considered a unitary phenomenon, with a stratigraphic record that began with the oldest known sedimentary rocks and essentially ended 19001800 million years ago. Better age control, however, now makes it clear that 1900 to 1800 $\mathrm{Ma}$ iron formations reflect a resurgence rather than a culmination of iron deposition in early oceans; only minor amounts of iron formation were deposited between $2400 \mathrm{Ma}$, when oxygen began to accumulate, and 1900-1800 Ma, when sedimentologically distinct iron formations once again accumulated across North America and Australia (Fig. 3) (Bekker et al. 2010). The resurgence of iron deposition has been linked to rapid crustal growth and exceptionally large plumes of mantle-derived magma (e.g., Rasmussen et al. 2012), a hypothesis that finds support in the distinctive Si isotopic composition of 1900- to $1800 \mathrm{Ma}$ cherts (Chakrabarti et al. 2012).

The modern era of Precambrian paleontology actually began with the discovery of microfossils in cherty iron formation of the 1900to $1850 \mathrm{Ma}$ Gunflint Formation, Ontario (Barghoorn and Tyler 1965). Unlike most other microfossils in Proterozoic cherts, those of the Gunflint and other contemporaneous iron formations (references in Wilson et al. 2010) do 

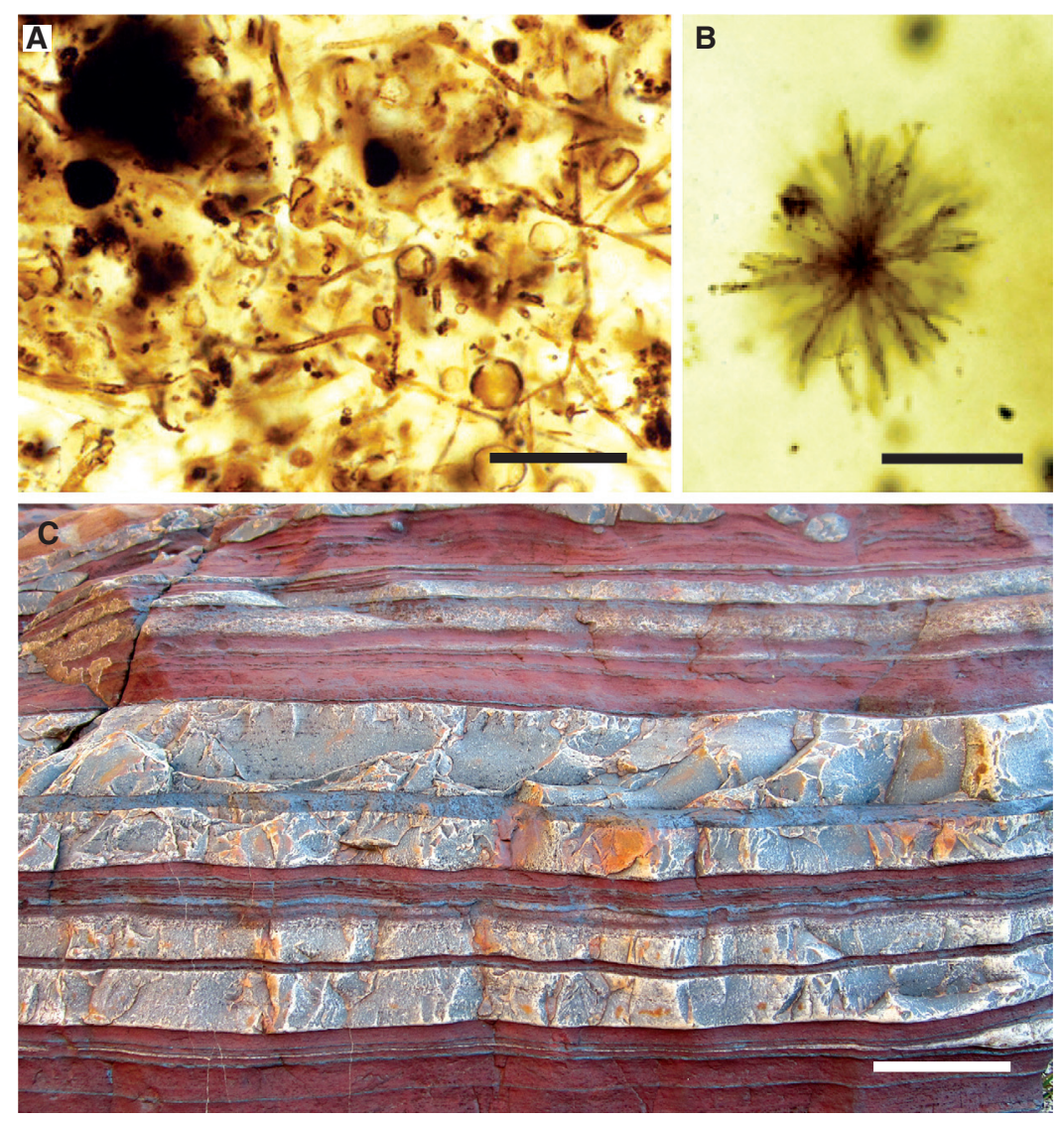

Figure 4. Iron formations and their paleobiology. (A) Filamentous and coccoidal microfossils in stromatolitic iron formation of the 1900 to 1850 Ma Gunflint Formation, Ontario. (B) Unusual microfossil in basinal chert of the Gunflint Formation. $(C)$ Banded iron formation, 2480 to 2495 Ma Brockman Iron Formation, Western Australia; reddish and whitish bands reflect iron- and silica-rich layers, respectively. Scale bars, $25 \mu \mathrm{m}(A)$; $10 \mu \mathrm{m}(B) ; 3 \mathrm{~cm}(C)$.

not closely resemble modern cyanobacteria. Rather, the thin (1-2 $\mu \mathrm{m})$, hematite-flecked filamentous sheaths that dominate Gunflint assemblages compare closely with modern ironoxidizing bacteria, such as Leptothrix (Fig. 4A) (Cloud 1965). Subdominant cocci 3-15 $\mu \mathrm{m}$ in diameter show little evidence of binary fission and commonly have circular openings in their walls, leading Strother and Tobin (1987) to interpret them as spores. Diverse but less common microfossils include both probable iron bacteria and possible planktonic cyanobacteria (Fig. 4B) (Awramik and Barghoorn 1977; Knoll et al. 1978). Local pyritization of Gunflint filaments appears to reflect sulfate-reducing bacte- ria that joined Fe-respirers in completing the local carbon cycle (Wacey et al. 2013). The restriction of these assemblages to environments near the redoxcline and iron isotopic abundances consistent with chemoautotrophic iron oxidation lend further support to the view that Gunflint-type assemblages reflect distinctive microbial communities fueled by iron (Planavsky et al. 2009; Wilson et al. 2010).

In general, then, the microbiology of Proterozoic oceans can be interpreted by reference to living microbes and their metabolisms, albeit operating within a world that was environmentally distinct from today's. Through the second half of the Proterozoic Eon, eukaryotes became 
A.H. Knoll

increasingly important in marine communities (Knoll 2014), eventually rivaling cyanobacteria as primary producers and adding functional complexity to heterotrophic parts of the carbon cycle, but the fundamental importance of microbial pathways in biogeochemical cycles remained unchanged.

\section{PROBLEMS OF ARCHEAN PALEOBIOLOGY}

The Archean-Proterozoic boundary is currently defined as $2500 \mathrm{Ma}$, a round number relatively close to the first great influx of $\mathrm{O}_{2}$ into the atmosphere and surface oceans at 2450-2320 million years ago (Fig. 3) (Holland 2006). As we have seen, when the geologic curtain rises on the moderately oxic Proterozoic biosphere, the paleobiological record seems to reflect extant microbial clades and familiar metabolisms. How far back can this record be traced?

That turns out to be a hard question to answer. First of all, the sedimentary record decays as an approximate power-law function of age (Veizer and Jansen 1985) and, for much of the Archean, there is not much left to examine. Moreover, only in the late Archean Eon did large stable cratons emerge-continent-scale masses of granitic crust that decreased the probability of both metamorphic and hydrothermal alteration of sedimentary successions (Cawood et al. 2013). On average, then, surviving Archean rocks are both fewer and less well preserved than their Proterozoic counterparts. In part, for these reasons, Earth scientists generally agree that life existed when the oldest known sedimentary rocks formed, but debate many of the observations used to support this conclusion.

The effects of hydrothermal fluid flow and metamorphism can be seen in the record of silicified microfossils, a rich source of information in Proterozoic deposits, but scarce and contentious in the Archean. Unambiguous microfossils occur in cherts of the 2500 to $2600 \mathrm{Ma}$ Transvaal Supergroup, South Africa, one of the earliest carbonate platforms developed on a large craton (Lanier 1986; Klein et al. 1987; Altermann and Schopf 1995). These fossils could be cyanobacterial, but unlike $2000 \mathrm{Ma}$ assemblages from Canada (Hofmann 1976), their simplicity, relatively poor preservation, and deposition in an anoxic environment (obviating any simple assumptions about electron donors) make systematic interpretation difficult.

Candidate microfossils in older cherts are few, with most reports focused on 3000$3500 \mathrm{Ma}$ successions in South Africa and Australia. Carbonaceous microstructures in these cherts include $<10-50 \mu \mathrm{m}$ spheroids, some in loose clusters; unusual spindle-shaped bodies; and, less commonly, solid or hollow filaments (Walsh 1992; Schopf 1993; Rasmussen 2000; Grey and Sugitani 2009; Sugitani et al. 2009a,b, 2010, 2013). Some, especially clusters of uniform spheroids and rare hollow filamentous sheaths, broadly resemble unambiguous microfossils in younger rocks, whereas others differ morphologically from both uncontested microfossils and most living microorganisms.

What are the alternatives for interpretation? At least some Archean microstructures could be nonbiological features that reflect hydrothermal alteration and associated migration of organic carbon (e.g., Brasier et al. 2005; Sforna et al. 2014). Migrating organics can be adsorbed onto mineral grains, and this is clearly evident in early Archean cherts (Knoll 2012); spheroidal and solid filamentous structures can also selforganize during metamorphism. Careful investigation shows that some Archean cherts contain multiple generations of silica and organic matter, underscoring the need for caution in paleobiological interpretation (Marshall et al. 2012). There is an understandable tendency to compare Archean microstructures to wellpreserved fossils in younger rocks, but more telling comparisons might be made to younger, hydrothermally altered rocks; where this has been performed, the results are sobering (e.g., Kazmierczak and Kremer 2009).

Biological interpretations of Archean microstructures find support in NanoSIMS analyses, which show consistent elemental and C-isotopic abundances within morphological classes, but differences among them (Oehler et al. 2010; Lepot et al. 2013). Also, a few early Archean populations show evidence of binary division and/or differentiated internal contents (Knoll and Barghoorn 1977; Sugitani et al. 2009b). In 
combination, then, microchemistry and morphology suggest that at least some Archean microstructures may be correctly interpreted as microfossils. If fossils, however, these populations lack the diverse and distinctive morphologies attributed to cyanobacteria in Proterozoic rocks. Therefore, confidence in phylogenetic or physiological interpretation is low. Early Archean rocks also contain micron-scale structures interpreted by some as bacteria (Westall 2008) and more widely accepted microscopic borings attributed to endolithic bacteria (Furnes et al. 2007; but see Grosch and McLoughlin 2014). Interestingly, some of the most convincing Archean microfossils come from shales. Javaux et al. (2010) reported compressed spheroidal envelopes up to $300 \mu \mathrm{m}$ in diameter from 3200 Ma shales in South Africa. These structures are convincingly biological, but, again, their phylogenetic affinities remain conjectural.

Other lines of evidence illuminate early physiologies. C-isotopic analyses of carbonateorganic carbon pairs show a consistent fractionation of $25 \%-35 \%$, much like younger rocks (Schopf 2006), suggesting that by 3500 million years ago, Earth had a biologically driven carbon cycle. Abiotic organic syntheses also fractionate C-isotopes (McCollom et al. 2010), but abiotic fractionation comparable to that observed in early Archean sedimentary rocks may require conditions unlikely to have been widespread on the early Earth. Moreover, isotopically light organic matter was deposited over wide expanses of early Archean seafloor, suggesting not only biological carbon fixation but photoautotrophy. ${ }^{13} \mathrm{C}$-depleted graphite in metamorphosed sedimentary rocks $>3700 \mathrm{Ma}$ is consistent with a still earlier origin of the biological carbon cycle (Rosing 1999; Ohtomo et al. 2014).

Given that the Archean biosphere was essentially oxygen free, how was organic carbon recycled? Without $\mathrm{O}_{2}$, aerobic respiration could not have proceeded, and absent the oxidative weathering of pyrite as a source of sulfate ions to the oceans, microbial sulfate reduction must have been limited, as was nitrate respiration (Canfield et al. 2006). In contrast, $\mathrm{Fe}^{2+}$ was widely distributed in Archean seawater, serving as the princi- pal electron donor for early photosynthesis (Canfield et al. 2006); $\mathrm{Fe}^{3+}$ generated by autotrophs, photochemical oxidation, or weathering would, in turn, have provided a major source of electron acceptors for Archean respiration. Indeed, the geochemistry of Archean iron formations suggests that, on the early Earth, the biological carbon and iron cycles were closely linked (Konhauser et al. 2005, Fischer and Knoll 2009).

Fermentation and methanogenesis would also have played important roles in cycling carbon. Organic carbon in 2800 to 2400 Ma rocks can be depleted in ${ }^{13} \mathrm{C}$ by as much as $60 \%$, a distinctive isotopic signature reflecting coupled methanogenesis and methanotrophy (Hayes 1994). Thermally altered lipids in $2700 \mathrm{Ma}$ metasedimentary rocks provide independent evidence for late Archean Archaea (Ventura et al. 2007); contamination hovers as an issue over all reports of Archean biomarker molecules (Brocks 2011), but, in this case, lipid emplacement appears to have predated peak late Archean metamorphism. ${ }^{13} \mathrm{C}$-depleted methane in fluid inclusions within $3470 \mathrm{Ma}$ cherts suggests that Bacteria-Archaea divergence occurred still earlier (Ueno et al. 2006).

Despite low Archean sulfate abundances, Sisotopic fractionation recorded in sedimentary pyrites also suggests an early origin for biological sulfate (or sulfur) reduction. Again, however, one must consider abiological fractionation. In an anoxic atmosphere, photochemical processes would fractionate $S$ isotopes in a massindependent fashion, and so careful analyses of all four stable $S$ isotopes can constrain paleobiological interpretation (Johnston 2011). Available data indicate that both biological and abiotic processes cycled sulfur on the early Earth (Shen et al. 2001; Philippot et al. 2007; Roerdink et al. 2012).

Stromatolites occur in Archean carbonates, and, once again, the issue is to what extent physical processes can mimic biologically influenced form and fabric. Stromatolites that accrete when microbial mats trap and bind fine sediment particles have textural features not easily generated by physical processes alone. In contrast, accretion by precipitation can build laminated structures with or without mat communities 
A.H. Knoll

(Grotzinger and Knoll 1999). In Proterozoic oceans, stromatolites accreted principally by trapping and binding, but in earlier Archean successions, precipitated forms predominate. Many of the stromatolites in the ca. $3400 \mathrm{Ma}$ Warrawoona Group, Australia (Fig. 4D) reflect principal control by physical chemistry (Wacey 2010), but a few details of morphology and petrology flag the presence of microbial mats (Hofmann 1999; Allwood et al. 2006, 2009). Further evidence for mats comes from ripped up and redeposited sheets of organic material (Walsh 1992; Tice and Lowe 2004) and, in younger Archean successions, microbially induced textures on sandstone bed surfaces (Noffke et al. 2008). Tice and Lowe (2006) proposed that hydrogen provided electrons for photosynthesis in early Archean ecosystems, but, in reality, we know little about mat communities 3400 Ma.

In general, then, it seems that by the time we get our first reasonably clear view of the Earth's surface, at 3400-3500 million years ago, life was already present. Mat communities were widely distributed, and carbon and sulfur were cycled via linked anaerobic metabolisms. Iron very likely played a key role in driving the microbial carbon cycle (Fig. 3). When did cyanobacteria, with their metabolic potential to reorganize the biosphere, enter the picture?

A minimum date for crown group cyanobacteria is provided by the initial oxygenation of the atmosphere and surface ocean at 2450$2320 \mathrm{Ma}$ - there is simply no alternative to photosynthesis for the volume of oxygen that accumulated at this time. Molecular clocks, calibrated on the basis of Proterozoic fossils and younger archaeplastid taxa, provide only broad constraints, but recent studies suggest cyanobacterial emergence well before the oxygenation event (Falcón et al. 2010; Schirrmeister et al. 2013). If correct, and the uncertainties are large, this requires processes capable of inhibiting oxygen accumulation for up to several hundred million years.

Late Archean stromatolites and carbon isotopes are perfectly consistent with cyanobacterial emergence 2700 million years ago or earlier (Buick 2008), but, as already discussed, in the absence of unambiguous microfossils or evidence of atmospheric oxygen, it is difficult to rule out alternative interpretations. Bosak et al. (2009) proposed that $3000 \mathrm{Ma}$ stromatolites were built by cyanobacteria, citing fabrics generated by gas bubbles. Oxygenic photosynthesis is the one photoautotrophic pathway that produces gas as a by-product, although methanogenesis within mats provides an alternative gas source. Microfossils provide little insight. The morphologically distinctive cyanobacterial populations preserved in younger rocks are not evident in Archean cherts, but it remains an open question whether this reflects the evolutionary absence of blue-greens or the taphonomic consequences of hydrothermal fluid flow and an Archean Si cycle strongly influenced by iron (Fischer and Knoll 2009). Mo and other trace metal abundances have also been used to infer local oxygen accumulation before 2400 million years ago (Anbar et al. 2007; Wille et al. 2007). The "whiff of oxygen" hypothesis draws support from several geochemical quarters, but is not without its uncertainties (Farquhar et al. 2011) and critics (e.g., Johnson et al. 2013). The case for cyanobacteria-generated oxygen oases in Archean oceans continues to grow, but when oxygenic photosynthesis first evolved remains a major question in microbial paleobiology.

\section{CONCLUSIONS}

The geologic record shows that Earth has been a biological planet for at least 3500 million years and was an exclusively microbial planet for much of this time. During the first billion years of recorded Earth history, ecosystems were largely, if not entirely, anoxic, and so the microbial cycling of carbon and other elements involved an expansive array of electron donors but a narrower list of electron acceptors. About 2400 million years ago, cyanobacteria transformed the Earth, as photosynthetic oxygen production began to outstrip oxygen consumption. Oxygen levels in the atmosphere and surface ocean may have spiked during the great oxygenation event (Partin et al. 2013), but soon fell to modest levels, perhaps no more than a few percent of the present day, and re- 
mained low until near the end of the Proterozoic Eon. Accumulating $\mathrm{O}_{2}$ limited the diversity of electron donors in surficial environments, whereas building the reservoirs of electron acceptors, including sulfate and, eventually, nitrate aerobiosis dramatically expanded biosynthetic capacity among microorganisms (Raymond and Segre 2006). Nonetheless, in the ocean subsurface, anoxia remained common.

About 570-550 million years ago, oxygen levels increased again, heralding the radiations of large complex animals and, later, plants. Profound as it was, this biological state change did little to diminish the fundamental roles of microbes in functioning ecosystems. Cyanobacteria still account for nearly a quarter of all photosynthesis and the rest is accomplished by plastids, the modified descendants of cyanobacteria. Similarly, microbial metabolisms remain important in heterotrophic carbon cycling, and microbes still define the metabolic pathways by which other biologically important elements are cycled. Every animal on Earth probably contains microbial symbionts and is subject to microbial pathogens (e.g., McFall-Ngai et al. 2013). From a microbial perspective, then, the radiations of complex multicellular eukaryotes simply expanded their evolutionary opportunities, providing new kingdoms to conquer.

\section{ACKNOWLEDGMENTS}

I thank the National Aeronautics and Space Administration (NASA) Astrobiology Institute for support that led to this paper.

\section{REFERENCES}

Allwood AC, Walter MR, Kamber BS, Marshall CP, Burch IW. 2006. Stromatolite reef from the Early Archaean era of Australia. Nature 441: 714-718.

Allwood AC, Grotzinger JP, Knoll AH, Burch IW, Anderson MS, Coleman ML, Kanik I. 2009. Controls on development and diversity of Early Archean stromatolites. Proc Natl Acad Sci 106: 9548-9555.

Altabet MA, Francois R. 1994. Sedimentary nitrogen isotopic ratio as a recorder of surface nitrate utilization. Global Biogeochem Cycles 8: 103-116.

Altermann W, Schopf JW. 1995. Microfossils from the Neoarchean Campbell Group, Griqualand West sequence of the Transvaal Supergroup, and their paleoenviron- mental and evolutionary implications. Precambrian Res 75: 65-90.

Amard B, Bertrand-Sarfati J. 1997. Microfossils in $2000 \mathrm{Ma}$ cherty stromatolites of the Franceville Group, Gabon. Precambrian Res 81: 197-221.

Anbar AD, Knoll AH. 2002. Proterozoic ocean chemistry and evolution: A bioorganic bridge? Science 297: $1137-$ 1142.

Anbar AD, Roe JE, Barling J, Nealson KH. 2000. Nonbiological fractionation of iron isotopes. Science 288: $126-$ 128.

Anbar AD, Duan Y, Lyons TW, Arnold GL, Kendall B, Creaser RA, Kaufman AJ, Gordon GW, Scott C, Garvin J, et al. 2007. A whiff of oxygen before the great oxidation event? Science 317: 1903-1906.

Awramik SM, Barghoorn ES. 1977. Gunflint microbiota. Precambrian Res 5: 121-142.

Badger MRT, Andrews J, Whitney SM, Ludwig M, Yellowlees DC, Leggat W, Price GD. 1998. The diversity and coevolution of Rubisco, plastids, pyrenoids, and chloroplastbased $\mathrm{CO}_{2}$-concentrating mechanisms in algae. Can J Bot 76: $1052-1071$.

Badger MR, Hanson D, Price GD. 2002. Evolution and diversity of $\mathrm{CO}_{2}$ concentrating mechanisms in cyanobacteria. Funct Plant Biol 29: 161-173.

Barghoorn ES, Tyler SA. 1965. Microorganisms from the Gunflint Chert. Science 147: 563-575.

Bartley JK. 1996. Actualistic taphonomy of cyanobacteria: Implications for the Precambrian fossil record. Palaios 11: $571-586$.

Bekker A, Slack JF, Planavsky N, Krapež B, Hofmann A, Konhauser KO, Rouxel OJ. 2010. Iron formation: The sedimentary product of a complex interplay among mantle, tectonic, oceanic, and biospheric processes. Econ Geol 105: 467-508.

Bosak T, Liang B, Min S, Petroff AP. 2009. Morphological record of oxygenic photosynthesis in conical stromatolites. Proc Natl Acad Sci 106: 10939-10943.

Bosak T, Knoll AH, Petroff AP. 2013. The meaning of stromatolites. Annu Rev Earth Planet Sci 41: 21-44.

Boyle RA, Clark JR, Poulton SW, Shields-Zhou G, Canfield DE, Lenton TM. 2013. Nitrogen cycle feedbacks as a control on euxinia in the mid-Proterozoic ocean. Nat Commun 4: 1533

Bradley AS, Leavitt WD, Johnston DT. 2011. Revisiting the dissimilatory sulfate reduction pathway. Geobiology 9: 446-457.

Brasier MD, Green OR, Lindsay JF, McLoughlin N, Steele A, Stoakes C. 2005. Critical testing of Earth's oldest putative fossil assemblage from the $\sim 3.5 \mathrm{Ga}$ Apex chert, Chinaman Creek, Western Australia. Precambrian Res 140: 55 102.

Briggs DEG, Summons RE. 2014. Ancient biomolecules: Their origins, fossilization, and role in revealing the history of life. Bioessays 36: 482-490.

Brocks JJ. 2011. Millimeter-scale concentration gradients of hydrocarbons in Archean shales: Live-oil escape or fingerprint of contamination? Geochim Cosmochim Acta 75: 3196-3213.

Brocks JJ, Love GD, Summons RE, Knoll AH, Logan GA, Bowden S. 2005. Biomarker evidence for green and pur- 
A.H. Knoll

ple sulfur bacteria in an intensely stratified Paleoproterozoic ocean. Nature 437: 866-870.

Buick R. 2008. When did oxygenic photosynthesis evolve? Phil Trans Roy Soc B Biol Sci 363: 2731-2743.

Canfield DE. 2001. Biogeochemistry of sulfur isotopes. Rev Mineral Geochem 43: 607-636.

Canfield DE, Teske A. 1996. Late Proterozoic rise in atmospheric oxygen concentration inferred from phylogenetic and sulphur-isotope studies. Nature 382: 127-132.

Canfield DE, Rosing MT, Bjerrum C. 2006. Early anaerobic metabolisms. Phil Trans Roy Soc B Biol Sci 361: 18191834.

Cawood PA, Hawkesworth CJ, Dhuime B. 2013. The continental record and the generation of continental crust. Geol Soc Am Bull 125: 14-32.

Chakrabarti R, Knoll AH, Jacobsen SB, Fischer WW. 2012. Silicon isotopic variability of Proterozoic cherts. Geochim Cosmochim Acta 91: 187-201.

Cloud PE Jr. 1965. Significance of the Gunflint (Precambrian) microflora: Photosynthetic oxygen may have had important local effects before becoming a major atmospheric gas. Science 148: 27-35.

Dworkin M. 2006. Prokaryotic life cycles. In The prokaryotes, Vol. 2: Ecophysiology and biochemistry (ed. Dworkin M, Falkow S, Schliefer K.-H, Stackebrandt E), pp. 140 166. Springer, Berlin.

Eickhoff M, Birgel D, Talbot HM, Peckmann J, Kappler A 2013. Bacteriohopanoid inventory of Geobacter sulfurreducens and Geobacter metallireducens. Org Geochem 58: $107-114$.

Falcón LI, Magallón S, Castill A. 2010. Dating the cyanobacterial ancestor of the chloroplast. ISME J 4: 777-783.

Farquhar J, Zerkle AL, Bekker A. 2011. Geological constraints on the origin of oxygenic photosynthesis. Photosynthesis Res 107: 11-36.

Fennel K, Follows M, Falkowski PG. 2005. The co-evolution of the nitrogen, carbon and oxygen cycles in the Proterozoic ocean. Am J Sci 305: 526-545.

Fischer WW, Knoll AH. 2009. An iron shuttle for deepwater silica in Late Archean and early Paleoproterozoic iron formation. Geol Soc Am Bull 121: 222-235.

Fischer WW, Summons RE, Pearson A. 2005. Targeted genomic detection of biosynthetic pathways: Anaerobic production of hopanoid biomarkers by a common sedimentary microbe. Geobiology 3: 33-40.

Furnes H, Banerjee NR, Staudigel H, Muehlenbachs K, McLoughlin N, de Wit M, Van Kranendonk M. 2007. Comparing petrographic signatures of bioalteration in recent to Mesoarchean pillow lavas: Tracing subsurface life in oceanic igneous rocks. Precambrian Res 158: 156176.

Gilleaudeau GJ, Kah LC. 2013. Carbon isotope records in a Mesoproterozoic epicratonic sea: Carbon cycling in a low-oxygen world. Precambrian Res 228: 85-101.

Giordano M, Beardall J, Raven JA. 2005. $\mathrm{CO}_{2}$ concentrating mechanisms in algae: Mechanisms, environmental modulation, and evolution. Annu Rev Plan Biol 56: 99-131.

Glass JB, Wolfe-Simon F, Anbar AD. 2009. Coevolution of metal availability and nitrogen assimilation in cyanobacteria and algae. Geobiology 7: 100-123.
Golubic S, Campbell SE. 1979. Analogous microbial forms in recent subaerial habitats and in Precambrian cherts: Gloeothece coerulea Geitler and Eosynechococcus moorei Hofmann. Precambrian Res 8: 201-217.

Golubic S, Hofmann HJ. 1976. Comparison of Holocene and mid-Precambrian Entophysalidaceae (Cyanophyta) in stromatolitic algal mats: Cell division and degradation. J Paleontol 50: 1074-1082.

Golubic S, Sergeev NV, Knoll AH. 1995. Mesoproterozoic Archaeoellipsoides: Akinetes of heterocystous cyanobacteria. Lethaia 28: 285-298.

Green J, Knoll AH, Golubic S, Swett K. 1987. Paleobiology of distinctive benthic microfossils from the upper Proterozoic Limestone-Dolomite "Series," central East Greenland. Am J Bot 74: 928-940.

Green J, Knoll AH, Swett K. 1988. Microfossils in oolites and pisolites from the Upper Proterozoic Eleonore Bay Group, Central East Greenland. J Paleontol 62: 835-852.

Grey K, Sugitani K. 2009. Palynology of Archean microfossils (c. $3.0 \mathrm{Ga}$ ) from the Mount Grant area, Pilbara Craton, Western Australia: Further evidence of biogenicity. Precambrian Res 173: 60-69.

Grosch EG, McLoughlin N. 2014. Reassessing the biogenicity of Earth's oldest trace fossil with implications for biosignatures in the search for early life. Proc Natl Acad Sci 111: $8380-8385$.

Grotzinger JP, Knoll AH. 1999. Proterozoic stromatolites: Evolutionary mileposts or environmental dipsticks? Annu Rev Earth Planet Sci 27: 313-358.

Hayes JM. 1994. Global methanotrophy at the Archean-Proterozoic transition. In Early life on Earth (ed. Bengtson S), pp. 220-236. Columbia University Press, New York.

Hayes JM. 2001. Fractionation of carbon and hydrogen isotopes in biosynthetic processes. Rev Mineral Geochem 43: $225-278$.

Hofmann HJ. 1976. Precambrian microflora, Belcher Islands, Canada: Significance and systematics. J Paleontol 50: $1040-1073$.

Hofmann HJ, Grey K, Hickman AH, Thorpe RI. 1999. Origin of $3.45 \mathrm{Ga}$ coniform stromatolites in Warrawoona Group, Western Australia. Geol Soc Am Bull 111: 12561262.

Holland HD. 2006. The oxygenation of the atmosphere and oceans. Phil Trans R Soc London B Biol Sci 361: 903-915.

Horodyski RJ, Donaldson JA. 1980. Microfossils from the Middle Proterozoic Dismal Lakes Group, arctic Canada. Precambrian Res 11: 125-159.

Javaux EJ, Marshall CP, Bekker A. 2010. Organic-walled microfossils in 3.2 billion-year-old shallow-marine siliciclastic deposits. Nature 463: 934-938.

Johnson JE, Webb SM, Thomas K, Ono S, Kirschvink JL, Fischer WW. 2013. Manganese oxidizing photosynthesis before the rise of cyanobacteria. Proc Natl Acad Sci 110: $11238-11243$.

Johnston DT. 2011. Multiple sulfur isotopes and the evolution of Earth's surface sulfur cycle. Earth Sci Rev 106: 161-183.

Johnston DT, Wing BA, Farquhar J, Kaufman AJ, Strauss H, Lyons TW, Kah LC, Canfield DE. 2005. Active microbial sulfur disproportionation in the Mesoproterozoic. Science 310: 1477-1479. 
Johnston DT, Wolfe-Simon F, Pearson A, Knoll AH. 2009 Anoxygenic photosynthesis modulated Proterozoic oxygen and sustained Earth's middle age. Proc Natl Acad Sci 106: $16925-16929$.

Kappler A, Pasquero C, Konhauser KO, Newman DK. 2005. Deposition of banded iron formations by anoxygenic phototrophic $\mathrm{Fe}(\mathrm{II})$-oxidizing bacteria. Geology 33: 865-868.

Kasting JF. 1987. Theoretical constraints on oxygen and carbon dioxide concentrations in the Precambrian atmosphere. Precambrian Res 34: 205-229.

Kazmierczak J, Kremer B. 2009. Thermally altered Silurian cyanobacterial mats: A key to Earth's oldest fossils. Astrobiology 9: 731-743.

Klein C, Beukes NJ, Schopf JW. 1987. Filamentous microfossils in the early Proterozoic Transvaal Supergroup: Their morphology, significance, and palaeoenvironmental setting. Precambrian Res 36: 81-94.

Knoll AH. 2003. Life on a young planet: The first three billion years of evolution on Earth. Princeton University Press, Princeton, NJ.

Knoll AH. 2008. Cyanobacteria and Earth history. In The cyanobacteria: Molecular biology, genomics and evolution (ed. Herrero A, Flores E), pp. 1-19. Horizon Scientific, Heatherset, UK.

Knoll AH. 2012. The fossil record of microbial life. In Fundamentals of geobiology (ed. Knoll AH, Canfield DE, Konhauser K), pp. 297-314. Wiley-Blackwell, Chichester UK.

Knoll AH. 2014. Paleobiological perspectives on early eukaryotic evolution. Cold Spring Harbor Perspect Biol 6: a016121.

Knoll AH, Barghoorn ES. 1977. Archean microfossils showing evidence of cell division. Science 198: 396-399.

Knoll AH, Golubic S. 1979. Anatomy and taphonomy of a Precambrian algal stromatolite. Precambrian Res 10: $115-151$.

Knoll AH, Golubic S. 1992. Living and Proterozoic cyanobacteria. In Early organic evolution: Implications for mineral energy resources (ed. Schidlowski M, et al.), pp. 450462. Springer, Berlin.

Knoll AH, Barghoorn ES, Golubic S. 1975. Paleopleurocapsa wopfnerii gen. et sp. nov.: A Late Precambrian alga and its modern counterpart. Proc Natl Acad Sci 72: 2488-2492.

Knoll AH, Barghoorn ES, Awramik SM. 1978. New microorganisms from the Aphebian Gunflint Iron Formation, Ontario. J Paleontol 52: 976-992.

Knoll AH, Summons RE, Waldbauer J, Zumberge J. 2007. The geological succession of primary producers in the oceans. In The evolution of primary producers in the sea (ed. Falkowski P, Knoll AH), pp. 133-163. Elsevier, Burlington, MA.

Knoll AH, Canfield DE, Konhauser K (eds). 2012. Fundamentals of geobiology. Wiley-Blackwell, Chichester, UK.

Knoll AH, Wörndle S, Kah L. 2013. Covariance of microfossil assemblages and microbialite textures across a late Mesoproterozoic carbonate platform. Palaios 28: $453-$ 470.

Koga Y, Morii H. 2005. Recent advances in structural research on ether lipids from Archaea including comparative and physiological aspects. Biosci Biotechnol Biochem 69: 2019-2034.
Konhauser KO, Newman DK, Kappler A. 2005. The potential significance of microbial $\mathrm{Fe}(\mathrm{III})$ reduction during deposition of Precambrian banded iron formations. Geobiology 3: 167-177.

Kopp RE, Kirschvink JL. 2008. The identification and biogeochemical interpretation of fossil magnetotactic bacteria. Earth Sci Rev 86: 42-61.

Lanier WP. 1986. Approximate growth rates of Early Proterozoic microstromatolites as deduced by biomass productivity. Palaios 1: 525-542.

Lepot K, Williford KH, Ushikubo T, Sugitani K, Mimura K, Spicuzza MJ, Valley JW. 2013. Texture-specific isotopic compositions in 3.4 Gyr old organic matter support selective preservation in cell-like structures. Geochim Cosmochim Acta 112: 66-86.

Maliva R, Knoll AH, Siever R. 1989. Secular change in chert distribution: A reflection of evolving biological participation in the silica cycle. Palaios 4: 519-532.

Mankiewicz C. 1982. Obruchevella and other microfossils in the Burgess Shale: Preservation and affinity. J Paleontol 66: $717-729$.

Marshall AO, Emry JR, Marshall CP. 2012. Multiple generations of carbon in the Apex Chert and implications for preservation of microfossils. Astrobiology 12: 160-166.

McCollom TM, Lollar BS, Lacrampe-Couloume G, Seewald JS. 2010. The influence of carbon source on abiotic organic synthesis and carbon isotope fractionation under hydrothermal conditions. Geochim Cosmochim Acta 74: 2717-2740.

McFall-Ngai M, Hadfield MG, Bosch TCG, Carey HV, Domazet-Lošo T, Douglas AE, Dubilier N, Eberl G, Fukami T, Gilbert SF, et al. 2013. Animals in a bacterial world: A new imperative for the life sciences. Proc Natl Acad Sci 110: $3229-3236$.

Noffke N. 2010. Geobiology: Microbial mats in sandy deposits from the Archean era to today. Springer, Berlin.

Noffke N, Beukes N, Bower D, Hazen RM, Swift DJP. 2008. An actualistic perspective into Archean worlds-(Cyano-) bacterially induced sedimentary structures in the siliciclastic Nhlazatse Section, 2.9 Ga Pongola Supergroup, South Africa. Geobiology 6: 5-20.

Oehler DZ, Robert F, Walter MR, Sugitani K, Meibom A, Mostefaoui S, Gibson EK. 2010. Diversity in the Archean biosphere: New insights from NanoSIMS. Astrobiology 10: 413-424.

Ogren WL. 1984. Photorespiration: Pathways, regulation, and modification. Annu Rev Plant Physiol Plant Mol Biol 35: 415-442.

Ohtomo Y, Kakegawa T, Ishida A, Nagase T, Rosing MT. 2014. Evidence for biogenic graphite in early Archaean Isua metasedimentary rocks. Nat Geosci 7: 25-28.

Partin CA, Bekker A, Planavsky NJ, Scott CT, Gill BC, Li C, Podkovyrov V, Maslov A, Konhauser KO, Lalonde SV, et al. 2013. Large-scale fluctuations in Precambrian atmospheric and oceanic oxygen levels from the record of $U$ in shales. Earth Planet Sci Lett 369-370: 284-293.

Pearson A, Page SRF, Jorgenson TL, Fischer WW, Higgins MB. 2007. Novel hopanoid cyclases from the environment. Environ Microbiol 9: 2175-2188.

Percak-Dennett EM, Beard BL, Xu H, Konishi H, Johnson CM, Roden EE. 2011. Iron isotope fractionation during 
A.H. Knoll

microbial dissimilatory iron oxide reduction in simulated Archaean seawater. Geobiology 9: 205-220.

Philippot P, van Zuilen MA, Lepot K, Thomazo C, Farquhar J, Van Kranendonk MJ. 2007. Early Archaean micro-organisms preferred elemental sulfur, not sulfate. Science 317: 1534-1537.

Planavsky N, Rouxel O, Bekker A, Shapiro R, Fralick P, Knudsen A. 2009. Iron-oxidizing microbial ecosystems thrived in late Paleoproterozoic redox-stratified oceans. Earth Planet Sci Lett 286: 230-242.

Planavsky NJ, Reinhard CT, Wang XL, Thomson D, McGoldric P, Rainbird RH, Johnson T, Fischer WW, Lyons TW. 2014. Low Mid-Proterozoic atmospheric oxygen levels and the delayed rise of animals. Science 346: 635-638.

Rashby SE, Sessions AL, Summons RE, Newman DK. 2007. Biosynthesis of 2-methylbacteriohopanepolyols by an anoxygenic phototroph. Proc Natl Acad Sci 104: 15099-15104.

Rasmussen B. 2000. Filamentous microfossils in a 3,235million-year-old volcanogenic massive sulphide deposit. Nature 405: 676-679.

Rasmussen B, Fletcher IR, Bekker A, Muhling JR, Gregory CJ, Thorne AM. 2012. Deposition of 1.88-billion-yearold iron formations as a consequence of rapid crustal growth. Nature 484: 498-501.

Raymond J, Segre D. 2006. The effect of oxygen on biochemical networks and the evolution of complex life. Science 311: 1764-1767.

Rocap G, Distel DL, Waterbury JB, Chisholm SW. 2002. Resolution of Prochlorococcus and Synechococcus ecotypes by using $16 \mathrm{~S}-23 \mathrm{~S}$ ribosomal DNA internal transcribed spacer sequences. Appl Environ Microbiol 68: 1180-1191.

Roerdink DL, Mason PRD, Farquhar J, Reimer T. 2012. Multiple sulfur isotopes in Paleoarchean barites identify an important role for microbial sulfate reduction in the early marine environment. Earth Planet Sci Lett 331: $177-186$.

Rosing MT. 1999. ${ }^{13} \mathrm{C}$-depleted carbon microparticles in $>3700-\mathrm{Ma}$ sea-floor sedimentary rocks from west Greenland. Science 283: 674-676.

Saito MA, Sigman DM, Morel FMM. 2003. The bioinorganic chemistry of the ancient ocean: The co-evolution of cyanobacterial metal requirements and biogeochemical cycles at the Archean-Proterozoic boundary? Inorganica Chim Acta 356: 308-318.

Sánchez-Baracaldo P, Hayes PK, Blank CE. 2005. Morphological and habitat evolution in the cyanobacteria using a compartmentalization approach. Geobiology 3: 145-166.

Schirrmeister BE, de Vos JM, Antonelli A, Bagheri HC. 2013. Evolution of multicellularity coincided with increased diversification of cyanobacteria and the Great Oxidation Event. Proc Natl Acad Sci 110: 1791-1796.

Schopf JW. 1968. Microflora of the Bitter Springs Formation, Late Precambrian, central Australia. J Paleontol 42: 651-688.

Schopf JW. 1993. Microfossils of the Early Archean Apex chert: New evidence of the antiquity of life. Science 260: 640-646.

Schopf JW. 2006. Fossil evidence of Archean life. Phil Trans $R$ Soc B Biol Sci 361: 861-885.
Schopf JW. 2011. The paleobiological record of photosynthesis. Photosyn Res 107: 87-101.

Schopf JW, Blacic JN. 1971. New microorganisms from the Bitter Springs Formation (Late Precambrian) of the north-central Amadeus Basin, Australia. J Paleontol 45: 925-960.

Schopf JW, Walter MR. 1982. Origin and early evolution of cyanobacteria: The geological evidence. In The biology of cyanobacteria (ed. Carr NG, Whitton BA), pp. 543-564. University of California Press, Berkeley, CA.

Sergeev VN, Knoll AH, Grotzinger JP. 1995. Paleobiology of the Mesoproterozoic Billyakh Group, northern Siberia. Paleontol Soc Mem 39: 1-37.

Sforna MC, van Zuilen MA, Philippot P. 2014. Structural characterization by Raman hyperspectral mapping of organic carbon in the 3.46 billion-year-old Apex chert, Western Australia. Geochim Cosmochim Acta 124: 18-33.

Shanahan T. 2004. The evolution of Darwinism: Selection, adaptation and progress in evolutionary biology. Cambridge University Press, Cambridge.

Shen Y, Buick R, Canfield DE. 2001. Isotopic evidence for microbial sulfate reduction in the early Archaean era. Nature 410: 77-81.

Shi PM, Wu D, Latifi A, Axen SD, Fewer DP, Talla E, Calteau A, Cai F, Tandeau de Marsac N, Rippka R, et al. 2013. Improving the coverage of the cyanobacterial phylum using diversity-driven genome sequencing. Proc Natl Acad Sci 110: 1053-1058.

Sim SM, Bosak T, Ono S. 2011. Large sulfur isotope fractionation does not require disproportionation. Science 333: 74-77.

Sinninghe Damsté JS, Rijpstra WI, Geenevasen JA, Strous M, Jetten MS. 2005. Structural identification of ladderane and other membrane lipids of planctomycetes capable of anaerobic ammonium oxidation (anammox). FEBS J 272: $4270-4283$.

Srivastava P. 2005. Vindhyan akinetes: An indicator of Mesoproterozoic biospheric evolution. Origins Life Evol Biosph 35: 175-185.

Strother PK, Tobin K. 1987. Observations on the genus Huroniospora barghoorn: Implications for paleoecology of the Gunflint microbiota. Precambrian Res 36: $323-$ 333.

Stüeken EE. 2013. A test of the nitrogen-limitation hypothesis for retarded eukaryote radiation: Nitrogen isotopes across a Mesoproterozoic basinal profile. Geochem Cosmochim Acta 120: 121-139.

Sugitani K, Grey K, Nagaoka T, Mimura K, Walter MR. 2009a. Taxonomy and biogenicity of Archaean spheroidal microfossils (ca. 3.0 Ga) from the Mount GoldsworthyMount Grant area in the northeastern Pilbara Craton, Western Australia. Precambrian Res 173: 50-59.

Sugitani K, Grey K, Nagaoka T, Mimura K. 2009b. Threedimensional morphological and textural complexity of Archean putative microfossils from the northeastern Pilbara Craton: Indications of biogenicity of large $(>15 \mu \mathrm{m})$ spheroidal and spindle-like structures. Astrobiology 9: 603-615.

Sugitani K, Lepot K, Nagaoka T, Mimura K, Van Kranendonk M, Oehler DZ, Walter MR. 2010. Biogenicity of morphologically diverse carbonaceous microstructures 
from the ca. 3400 Ma Strelley Pool Formation, in the Pilbara Craton, Western Australia. Astrobiology 10: 899920.

Sugitani K, Mimura K, Nagaoka T, Lepot K, Takeuchi M. 2013. Microfossil assemblage from the $3400 \mathrm{Ma}$ Strelley Pool Formation in the Pilbara Craton, Western Australia: Results form a new locality. Precambrian Res 226: 59-74.

Summons RE, Lincoln SA. 2012. Biomarkers: Informative molecules for studies in geobiology. In Fundamentals of geobiology (ed. Knoll AH, Canfield DE, Konkauser K), pp. 269-296. Wiley-Blackwell, Chichester, UK.

Summons RE, Jahnke LL, Hope JM, Logan GA. 1999. 2Methylhopanoids as biomarkers for cyanobacterial oxygenic photosynthesis. Nature 400: 554-557.

Talbot HM, Summons RE, Jahnke LL, Cockell CS, Rohmer M, Farrimond P. 2008. Cyanobacterial bacteriohopanepolyol signatures from cultures and natural environmental settings. Org Geochem 39: 232-263.

Tcherkez GGB, Farquhar GD, Andrews TJ. 2006. Despite slow catalysis and confused substrate specificity, all ribulose bisphosphate carboxylases may be nearly perfectly optimized. Proc Natl Acad Sci 103: 7246-7251.

Tice MM, Lowe DR. 2004. Photosynthetic microbial mats in the 3,416-Myr-old ocean. Nature 431: 549-552.

Tice MM, Lowe DR. 2006. Hydrogen-based carbon fixation in the earliest known photosynthetic organisms. Geology 34: 37-40.

Tomitani A, Knoll AH, Cavanaugh CM, Ohno T. 2006. The evolutionary diversification of cyanobacteria: Molecular phylogenetic and paleontological perspectives. Proc Natl Acad Sci 103: 5442-5447.

Turner D. 2011. Paleontology: A philosophical introduction. Cambridge University Press, Cambridge.

Ueno Y, Yamada K, Yoshida N, Maruyama S, Isozaki Y. 2006. Evidence from fluid inclusions for microbial methanogenesis in the early Archaean era. Nature 440: 516-519.

Veizer J, Jansen SL. 1985. Basement and sedimentary recycling 2: Time dimension to global tectonics. J Geol 93: 625-643.

Ventura GT, Kenig F, Reddy CM, Schieber J, Frysinger GS, Nelson RK, Dinel E, Gaines RB, Schaeffer P. 2007. Molecular evidence of Late Archean Archaea and the pres- ence of a subsurface hydrothermal biosphere. Proc Natl Acad Sci 104: 14260-14265.

Wacey D. 2010. Stromatolites in the approximately $3400 \mathrm{Ma}$ Strelley Pool Formation, Western Australia: Examining biogenicity from the macro- to the nano-scale. Astrobiology 10: 381-395.

Wacey D, McLoughlin N, Kilburn MR, Saunders M, Cliff JB, Kong C, Barley ME, Brasier MD. 2013. Nanoscale analysis of pyritized microfossils reveals differential heterotrophic consumption in the similar to 1.9-Ga Gunflint chert. Proc Natl Acad Sci 110: 8020-8024.

Walsh MM. 1992. Microfossils and possible microfossils from the Early Archean Onverwacht Group, Barberton Mountain Land, South Africa. Precambrian Res 54: 271 293.

Walter MR. 1976. Stromatolites. Elsevier, Amsterdam.

Welander PV, Coleman M, Sessions AL, Summons RE, Newman DK. 2010. Identification of a methylase required for 2-methylhopanoid production and implications for the interpretation of sedimentary hopanes. Proc Natl Acad Sci 107: 8537-8542.

Westall F. 2008. Morphological biosignatures in early terrestrial and extraterrestrial materials. Space Sci Rev 135: 95114.

Wille M, Kramers JD, Nägler TF, Beukes NJ, Schröder S, Meisel T, Lacassie JP, Voegelin AR. 2007. Evidence for a gradual rise of oxygen between 2.6 and $2.5 \mathrm{Ga}$ from Mo isotopes and Re-PGE signatures in shales. Geochim Cosmochim Acta 71: 2417-2435.

Wilson JP, Fischer WW, Johnston DT, Knoll AH, Grotzinger JP, Walter MR, McNaughton NJ, Simon M, Abelson J, Schrag DP, et al. 2010. Geobiology of the Paleoproterozoic Duck Creek Formation, Western Australia. Precambrian Res 179: 135-149.

Zerkle AL, House CH, Cox RP, Canfield DE. 2006. Metal limitation of cyanobacterial $\mathrm{N}_{2}$ fixation and implications for the Precambrian nitrogen cycle. Geobiology 4: 285297.

Zhang Y, Golubic S. 1987. Endolithic microfossils (cyanophyta) from early Proterozoic stromatolites, Hebei, China. Acta Micropaleontol Sinica 4: 1-12. 


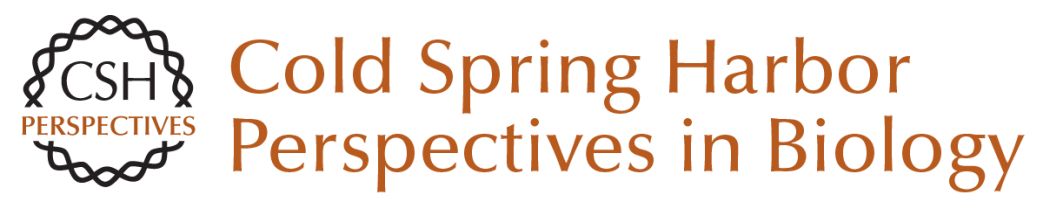

\section{Paleobiological Perspectives on Early Microbial Evolution}

Andrew H. Knoll

Cold Spring Harb Perspect Biol 2015; doi: 10.1101/cshperspect.a018093

Subject Collection Microbial Evolution

Not So Simple After All: Bacteria, Their Population Genetics, and Recombination

William P. Hanage

Realizing Microbial Evolution Howard Ochman

Thoughts Toward a Theory of Natural Selection: The Importance of Microbial Experimental Evolution

Daniel Dykhuizen

Coevolution of the Organization and Structure of Prokaryotic Genomes Marie Touchon and Eduardo P.C. Rocha

Mutation--The Engine of Evolution: Studying Mutation and Its Role in the Evolution of Bacteria Ruth Hershberg

The Origin of Mutants Under Selection: How Natural Selection Mimics Mutagenesis (Adaptive Mutation)

Sophie Maisnier-Patin and John R. Roth

Evolution of New Functions De Novo and from Preexisting Genes

Dan I. Andersson, Jon Jerlström-Hultqvist and Joakim Näsvall
Genome-Based Microbial Taxonomy Coming of Age

Philip Hugenholtz, Adam Skarshewski and Donovan H. Parks

Horizontal Gene Transfer and the History of Life Vincent Daubin and Gergely J. Szöllosi

Early Microbial Evolution: The Age of Anaerobes William F. Martin and Filipa L. Sousa

Microbial Speciation

B. Jesse Shapiro and Martin F. Polz

The Evolution of Campylobacter jejuni and Campylobacter coli

Samuel K. Sheppard and Martin C.J. Maiden

Paleobiological Perspectives on Early Microbial

Evolution

Andrew H. Knoll

For additional articles in this collection, see http://cshperspectives.cshlp.org/cgi/collection/

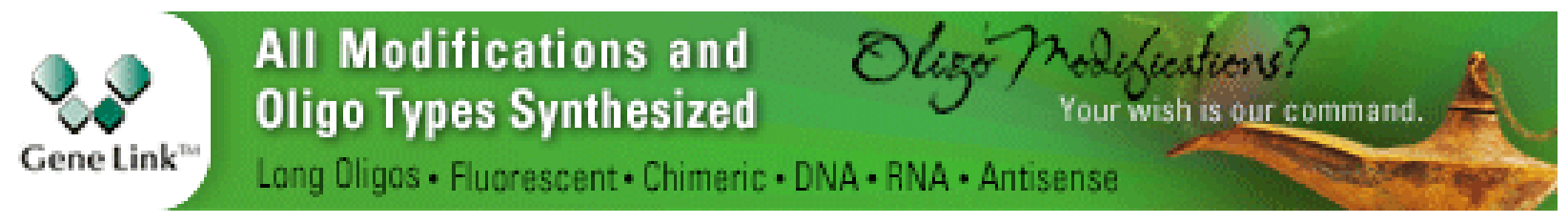

Copyright @ 2015 Cold Spring Harbor Laboratory Press; all rights reserved 